\title{
Considerações Acerca do Tribunal do Júri sob o Viés dos Direitos Humanos e das Garantias Constitucionais
}

\section{Paulo Roberto Silva Júnior}

Graduação em Direito (2018), com semestre cursado na Faculdade de Direito da Universidade de Coimbra - Portugal (2015.1), e Administração (2011), ambas pela Universidade Estadual da Paraíba, atuando, principalmente, nos temas concernentes à gestão ambiental, gestão pública e direitos sociais difusos e coletivos. Formação técnica, com láurea, em Meteorologia pela Universidade do Vale do Paraíba (2014). Monitor Bolsista UEPB do Componente Curricular de Direitos Sociais, Difusos e Coletivos (2016). Pós-graduado em Direito Processual Civil (2016). Estagiário no Ministério

Público da Paraíba (2017). Empregado público desde 2007. Orcid: <http://orcid.org/0000-0002-8130-043X>. <http://lattes.cnpq.br/3441450714956645>.paulorsj@yahoo.com.br

\section{Marcelo D’Angelo Lara}

Doutorando do PPGCJ/UFPB. Mestre em Direito Penal. Pós-graduado em Direito Público. Professor Universitário e Advogado criminalista. Orcid: <http://orcid.org/0000-0001-9350-3915>. prof.marcelo.lara@gmail.com

Este artigo visa a realizar uma breve análise livre de sessões do Tribunal do Júri, mormente em seu Conselho de Sentença. Trata-se de uma pesquisa indutiva, baseada na observação da praxis nos trabalhos do Tribunal do Júri e na literatura acadêmica especializada, sob o enfoque da lex fundamentalis que asseguram o devido processo legal, a segurança jurídica e o respeito à dignidade humana. Como objetivo, buscou-se confrontar a sistemática cênica e processual do Sinédrio Popular, o direito do réu ao silêncio e a repercussão sociomidiática do crime com os direitos humanos e as garantias constitucionais na formação de um Estado Democrático de Direito.

Palavras-chave: Tribunal do Júri. Conselho de sentença. Direitos humanos. Princípios. Constituição.

THE JURY TRIAL UNDER THE BIAS OF HUMAN RIGHTS AND CONSTITUTIONAL GUARANTEES

\section{ABSTRACT}

This article arises from the free analysis of several sessions of the trial by peers. It is an inductive research, based on observation of praxis in the work of the so-called imparcial Jury and specialized scholarly literature, under lex fundamentalis approach which ensures the due process of law, legal security and respect for human dignity. The purpose of the research is to confront the scenic and procedural systematic People's Court, the defendant's right to silence and the social and media impact of the crime to human rights and constitutional guarantees in the formation of a democratic state.

Keywords: Jury court. Council sentence. Human rights. Principles. Constitution.

1 Introdução. 2 O Tribunal do Júri. 3 Distasia Entre Jurados e Réu. 4 Fragilidade Substancial das Decisões. 5 Considerações Finais. 6 Referências.

Recebido em: 31/10/2017

Aceito em: 1일 $10 / 2018$ 


\section{Democracia}

Humanos e

\section{Introdução}

O presente construto visa a analisar o Tribunal do Júri sob o enfoque dos direitos humanos e das garantias constitucionais inerentes ao processo penal brasileiro. Estabelece como problemática, entre outros fatores, a influência de elementos externos no Conselho de Sentença, capazes de influenciar a construção do provimento jurisdicional de forma a contrariar os desígnios da Justiça e consolidar o mito do direito penal igualitário.

Cuida a investigação de empreender generalizações cognitivas, embasadas em pesquisa bibliográfica e na observação de fatos e comportamentos perceptíveis em sessões de julgamento de crimes dolosos contra a vida em plenário, construindo uma articulação didático-descritiva, de forma a estudar a compleição semiculta do Conselho de Sentença e as questões extrínsecas e intrínsecas que o conformam.

Trata-se de uma pesquisa indutiva, que traz como variável a livre percepção da sessão de julgamento em plenário como uma representação mimética, agregando-a a variantes dependentes das garantias constitucionais inerentes ao Processo Penal, sobretudo a presunção de inocência e o direito ao silêncio como fatores intervenientes às influências a pré-conceituações a que o membro do Sinédrio Popular é submetido durante o procedimento em apreço.

A elaboração partiu da hipótese de que o membro do Conselho de Sentença, em sua condição de juiz leigo, é submetido à ingerência de elementos astênicos, etiquetáveis, que podem induzi-lo à formação de juízos de valor em dissonância com os preceitos processuais mais austeros.

O trabalho tem como objetivo geral confrontar a sistemática cênica e processual do Tribunal Popular, direito do réu à não autoinculpação e a repercussão sociomidiática do crime com os direitos humanos e as garantias constitucionais na formação de um Estado Democrático de Direito. Como objetivo específico, transparece o interesse em demonstrar o caráter temerário da construção de sentença condenatória embasada em juízos de valores formulados por leigos, previamente etiquetados, muitas vezes prescindindo dos sustentáculos da própria sistemática processual penal.

\section{Tribunal do Júri}

Para além da função de justiça, o Tribunal do Júri funciona, na prática, como um teatro acusatorial, um jogo persuasivo mimético.

Segundo Aristóteles (1959), a mimese conta a imitação das ações reais da vida, da infelicidade e que resvalam na tragédia. Este processo mimético levaria àquilo que o sábio de Estagira designou catarse, ou seja, a obtenção, por intermédio da piedade e terror, da purificação ou purgação.

A mais bela tragédia é aquela cuja composição deve ser, não simples, mas complexa, aquela cujos fatos, por ela imitados, são capazes de excitar o temor e a compaixão (o terror e a piedade)... Em primeiro lugar, é óbvio não ser conveniente mostrar pessoas de bem passar da felicidade ao infortúnio... nem homens maus passando do crime à prosperidade... nem um homem completamente perverso deve tombar da felicidade no infortúnio (tal situação pode suscitar em nós um sentimento de humanidade, mas sem provocar compaixão nem temor- terror nem piedade)... Resta entre estes casos extremos a situa- 
ção intermediária: a do homem que, não se distinguindo por sua superioridade (virtude) e justiça, não obstante não é mau nem perverso, mas cai no infortúnio em conseqüência de qualquer falta (ARISTÓTELES, 1959).

Dessa forma, é possível vislumbrar a organização de um julgamento pelo Tribunal do Júri como uma arregimentação de emoções e sensações.

Longe, portanto, de qualquer conotação pejorativa assemelhada a uma bufonaria canastrona ou tartufista, o Tribunal do Júri funciona como uma autêntica representação dramático-épica de uma bela tragédia. Um espaço lúdico e teatralizado, lastreado em um sistema de persuasão performática, que encena o passado, cria personagens e histórias para dar senso de verossimilhança ao presente e, assim, reafirmar valores de antes para um futuro de mudança.

Seria apropriado, sob o escólio do dramaturgo alemão e poeta, Bertolt Brecht (1967), demiurgo da arte, vislumbrar a seguinte cena no palco cênico do Tribunal do Júri:

O espectador do teatro dramático diz: Sim, eu também senti isso. - É assim que eu sou. Sempre será assim. - $O$ sofrimento dessa pessoa me compunge porque não há saída para ela. - Isto é a verdadeira arte: tudo é evidente por si mesmo. - Eu choro com aqueles que estão chorando e rio com aqueles que estão rindo.

O espectador do teatro épico diz: Eu não teria pensado nisso. - Eu não teria pensado nisso. - Não se deve agir assim. - Isto é verdadeiramente extraordinário, é quase incrivel. - Isto não pode continuar. - O sofrimento desta pessoa me compunge porque sem dúvida haveria uma saída para ela. - Isto é a verdadeira arte: nada aí é evidente por si mesmo. Eu rio dos que estão chorando e choro dos que estão rindo.

Sob a perspectiva dramática, eis a síntese da dicotomia teatralizada a que se submete, instintivamente, o trâmite processual do Tribunal do Júri e, mais especificamente, que se impõe ao Conselho de Sentença - ponto fulcral deste artigo. No palco privilegiado dos plenários do Júri, o jurado-espectador deve sentir refundar e reforçar um sistema pessoal de crenças culturais, argamassado na lei, de modo que a dinâmica teórico-metodológica adotada lhe encete a perspectiva da conviç̧ão do voto:

Podemos afirmar, portanto, que o ritual dos julgamentos pelo Júri substantiva e dá materialidade ao social à medida que, nas histórias de vida e morte que chegam a essas arenas simbólicas, seus participantes produzem significados com vistas a justificar não apenas a absolvição ou a condenação de réus, mas a significação de todo um sistema de valores que qualifica vidas, mortes, ordem e desordem (SCHRITZMEYER, 2012, p. 136).

O julgamento pelo Tribunal do Júri reproduz uma pantomima voltada ao convencimento do espectador-jurado. Configura-se como uma espécie de tradição teatral de construção de um ideal de realidade, uma subversão real da interpretação da veracidade, diante de um arcabouço jurídico-normativo pré-determinado. Uma verdade particular, ficta, planificada pela força dramática da atuação performática dos polos envolvidos, adornada, unicamente, para persuadir e tentar superar o paradigma etiológico do labelling approach de que trata Alessandro Baratta (2002). 


\section{Humanos e}

Democracia

Esta estruturação solene do julgamento coteja traços do cerimonial fausto dos processos e execuções medievais, que Foucault (2008), acertadamente, denominou "ostentação do suplício". A obliteração das penas de suplício, contudo, paradoxalmente, não extinguiu a sequência protocolar de canalização das relações de poder, historicamente instituídas na morfologia social do julgamento público.

Assim, promotor público, defensor e réu são protagonistas da mise-en-scène. Sete jurados, fim último do espetáculo, completam-na. Manifestam-se em um desenlace determinado pela atuação narrativa e persuasiva das personagens principais.

Os jurados nunca leram o processo, quando muito ouviram o caso pela mídia. Eles têm que ser persuadidos pela fala do defensor ou acusador a formar uma opinião. Aquele que for mais persuasivo é quem vai levar ao desenlace. Fica muito claro que é um jogo que trabalha com estereótipos sociais e modelos de comportamento que são associados ao réu e à vítima. Tudo isso é muito forte no júri e faz com que os jurados formulem seus próprios valores (SCHRITZMEYER, 2012).

Há, por conseguinte, um nítido caráter estético do Júri, um jogo de atribuição de sentidos.

Dependendo de como as mortes são contadas, imaginadas e transformadas em imagens a serem julgadas, possíveis usos do poder de matar são socialmente legitimados ou não. Portanto, captar quais valores e motivações estruturam a legitimação desses usos é perceber como os participantes do Júri regulam não as mortes ocorridas, mas o andamento de suas próprias vidas. O fundamental, portanto, é entender o valor e o significado das imagens que manipulam as mortes, pois transcendem as necessidades imediatas da vida e alcançam significações mais amplas (SCHRITZMEYER, 2012, p. 49).

Por isso, Edilson Bonfim (2012) observa que Genuzio Bentini, douto jurisconsulto europeu, profetizou que "la verdad, la legítima, jamás es aquella que se conoce... Me he convencido de que la verdad no entra en la sala del Tribunal ni tampoco en pleito célebre alguno. Ella se ha quedado siempre en las escaleras o en la calle".

Não à toa, além do silêncio, neste espaço jurisdicional, tal como na arte ou no jogo, admite-se a não punibilidade da mentira: tudo é válido para aprazer o julgador-espectador.

Na prática, tal tradição dissocia a ideia de realidade, ou verdade, da ideia de lei. Quer dizer, a lei tem um caráter eminentemente normativo, de dever ser, e sua aplicação aos casos concretos depende, portanto, de interpretações que deem conta do caráter contingencial da realidade. É lógico que esta postura legislativa propicia uma postura interpretativa em relação à lei por parte daqueles encarregados de mantê-la ou aplicá-la (LIMA, 1982).

Neste diapasão, o princípio latino nemo tenetur se detegere é, no Processo Penal, uma garantia fundamental de liberdade do indivíduo acusado, oponível ao Estado-juiz e ao Estado-acusador, e, por obviedade, pressuposto de arregimentação da conduta processual em si. Cuida-se de um direito à não autoincriminação que resvala no direito ao silêncio. 
Logo, a garantia constitucional traz em seu escopo primário a tentativa de evitar-se o arbítrio do Estado, diante da dignidade da pessoa humana, e de infligir quaisquer métodos de constrangimento moral ou físico durante a persecutio criminis (QUEIJO, 2003). É o que sustenta Tourinho Filho (2007, p. 21):

Tal princípio consubstancia-se na velha parêmia audiatur etaltera pars - a parte contrária deve ser ouvida. Traduz a idéia que a defesa tem o direito de se pronunciar sobre tudo quanto for produzido em juízo pela parte contrária. Já disse: a todo ato produzido por uma das partes caberá igual direito da outra parte de opor-se-lhe ou de dar-lhe a versão que lhe convenha, ou, ainda, de dar uma interpretação jurídica diversa daquela apresentada pela parte ex adversa.

Cumpre destacar, entrementes, não ser o direito ao silêncio sinônimo do princípio nemo tenetur se detegere, senão parte imanente deste brocardo que, é, indubitavelmente, norma de primeira geração. Mesmo porque o Código de Processo Penal, em seu artigo 198, estabelece que o silêncio do réu pode constituir elemento para a formação do convencimento do juiz, ainda que, na prática, resulte em uma interpretação in pejus. Nesse diapasão,

o direito de silêncio é apenas uma manifestação de uma garantia muito maior, esculpida no princípio nemo tenetur se detegere, segundo a qual o sujeito passivo não pode sofrer nenhum prejuízo jurídico por omitir-se de colaborar em uma atividade probatória da acusação ou por exercer seu direito de silêncio quando interrogado e acrescenta que do exercício do direito ao silêncio não pode nascer nenhuma presunção de culpabilidade ou qualquer tipo de prejuízo jurídico ao imputado, na medida em que no processo penal só há presunção de inocência. Por consequência, qualquer tipo de recusa não autoriza presumir-se a culpabilidade, muito menor por configurar delito de desobediência. Portanto, o princípio da não autoincriminação decorre não só de poder calar no interrogatório, como também do fato de o imputado não poder ser compelido a participar de acareações, de reconhecimentos, de reconstituições, de fornecer material para exames periciais, tais como exame de sangue, de DNA ou de escrita, incumbindo à acusação desincumbir-se do ônus ou carga probatória de outra forma (LOPES JUNIOR, 2015, p. 192).

Acerca disto, deve-se repisar que o direito ao silêncio deflui de regra constitucional, mormente daquela disposta no artigo 5으, LXIII, colimada à supremacia da dignidade da pessoa humana e, em última análise, ao direito ao livre desenvolvimento da personalidade sob a perspectiva da presunção da não culpabilidade.

O direito de permanecer em silêncio, constitucionalmente consagrado, seguindo orientação da Convenção Americana sobre Direitos Humanos, que prevê em seu art. 8o, $\S 2^{\circ}$, alínea ' $\mathrm{g}$ ', o direito a toda pessoa acusada de delito não ser obrigada a depor contra si mesma, nem a declarar-se culpada, apresenta-se como verdadeiro complemento aos princípios do due process of law e da ampla defesa, garantindo-se dessa forma ao acusado não só o direito ao silêncio puro, mas também o direito a prestar declarações falsas e inverídicas, sem que por elas possa ser responsabilizado, uma vez que não se conhece em nosso ordenamento jurídico o crime de perjúrio (MORAES, 2000. p. 285).

Este delito não se subsume à atividade verborrágica do réu ou da testemunha, posto que não há reserva legal para este fato. A eles, portanto, faculta-se o direito ao silêncio - the right to stay mute ou ao nor shall be compelled in any criminal case to be a witness against himself previsto na 5a emenda à Constituição Norte-Americana -, e ao falseamento da verdade, limi- 


\section{Democracia}

Humanos

tando-se à afetação de direitos de terceiros. Vê-se que, conquanto ilegal, a materialidade do perjúrio perpetrado pelo réu é tida como atípica, embora, concomitantemente, antijurídica, formando uma espécie de figura anômala diante da impossibilidade do exercício legal de um direito consistir em ilicitude. Típico viés da tradição ibérica inquisitorial da ritualística penal, em que os polos querelantes merecem a desconfiança como matriz analítica para o livre convencimento dos magistrados de direito ou fato.

A possibilidade de o acusado faltar com a verdade no processo e justificada no Direito brasileiro pela garantia de vedação à autoincriminação adentra no ordenamento jurídico nacional a partir do Pacto de São José de Costa Rica.

[...] Há de se acentuar que, pelo simples fato de a mentira do acusado não ser proibida no sistema pátrio não significa que, em sentido técnico, isso seja revertido em um direito do acusado de faltar com a verdade no processo [...] (FERREIRA, 2010).

Nemo tenetur se detegere não se coaduna à impunidade, tampouco à incriminação inverídica de terceiros. Cuida-se de princípio típico do direito à ampla defesa, ilimitável por norma ordinária, mas que veda a autoinculpação falsa e tampouco permite obstaculizar o deslinde da verdade real dos fatos. Destarte, como constatação de que há limites ao direito do acusado à mentira, ao perscrutar-se a matéria, emerge à luz o crime de autoacusação falsa, por proibir que alguém se autoatribua, falsamente, a autoria de um crime, transtornando completamente o sistema penal, que punirá o inocente e deixará incólume o verdadeiro culpado, sob pena de detenção de três meses a dois anos (D'URSO, 2003).

Este direito está no ápice da pirâmide principiológica que rege, materialmente, o Tribunal do Júri. Nemo tenetur se detegere sacraliza a Justiça estatal e potencializa o jogo teatral, pois, para além das questões de Direito, revigora uma estética social e acentua, enormemente, a carga cênica e o poder imagético a que se submete o órgão jurisdicional popular.

O Júri se mantém porque umas "ilusões" teatrais que ele cria é a de que seus representantes são porta-vozes de valores universais. Ao julgarem dramas aparentemente interindividuais segundo valores aparentemente coletivos, juízes, promotores, defensores e jurados disfarçam, para si e para os outros, o caráter social dos dramas e o viés elitista e hierarquizado dos valores em que o sistema se pauta para julgá-los. Nesse mecanismo reside a criação da verossimilhança.

[...] A justiça praticada pelo Júri, apesar de todas as desigualdades que lhe são intrínsecas, em alguma medida é aceita e legitimada por seus participantes devido à ilusão teatral - e maniqueísta - de que uma justiça superior a todos os envolvidos está em jogo e em cena: a luta entre "bem" e "mal", certo e errado, perdão e punição, compreensão e vingança (SCHRITZMEYER, 2012, p. 176).

Exatamente nele compraz-se o cerne da erronia cênica, pois exsurge o deslocamento analítico da perspectiva teórica do criminoso para suas características objetivas, estruturais e funcionais, de modo a desviar a ontologia do estudo criminal ali posto em direção às implicações ideológicas, ao status atribuído às pessoas, acareando o valor do bem penalmente protegido ao rótulo do infrator (BARATTA, 2002). 
Entrementes, importa consignar que esta vivência paradigmática não é uma quimera brasílica, mas um princípio complexo, com duas faces, como Janus. Compartilhado alhures, também suscita controvérsias dogmáticas, mas sua aceitação, embora nem sempre, normativamente, explícita, vigora na maioria dos sistemas jurídicos ocidentais. Por exemplo, na República Portuguesa,

Sic a Lei Fundamental consagra no art. 32ำ ํo 2, o princípio da presunção de inocência, identificado por muitos autores, como princípio in dubio pro reo, no sentido de que um non liquet na questão da prova tem de ser sempre valorada a favor do arguido.

Em conformidade com este preceito constitucional (art. 32ㅇ, no 2, da CRP), o arguido goza do direito ao silêncio, sobre os factos que lhe forem imputados e sobre o conteúdo das declarações, para o que deve ser informado antes do interrogatório (arts. 141ำ, $\mathrm{n}$ 4, 143 ㅇ, n으, 144으, no 1, e 343으, no 1, do CPP), sendo que o silêncio do arguido não pode ser interpretado como presunção de culpa; ele presume-se inocente.

Por outro lado, "a lei não estabelece qualquer sanção para o arguido, que, prestando declarações sobre os factos que the forem imputados falte à verdade. Não se trata de um direito de mentir, mas simplesmente da não punição da mentira" (REPÚBLICA PORTUGUESA, 2004).

Precisamente neste jogo dicotômico e maniqueísta de verdades dramático-épicas, silêncio, mentiras permissíveis, interpretações lógico-performáticas e representação mimética da aparência como concretização do ideário social de Justiça, situa-se a processualística da persecutio criminis e, sob este pálio, majoritariamente, acusatorial, pairam quase despercebidos, mimetizados, os direitos humanos e a integralidade de um sistema de proteção holística à pessoa. Aqui encontra-se o maior desafio do Tribunal do Júri: compatibilizar a ortodoxia normativa deste teatro persuasivo diante da emergência do homem como ratio de existência do parênquima social.

A cristalização da imagem de uma sociedade íntegra, controladora dos seus desviantes e consternada com a miserabilidade da ação humana constitui a história sucinta do Tribunal do Júri. A linguagem de poder, ali utilizada, evoca o senso de justiça e sua força torna-se audível, visível e tangível por meio da teatralidade por que se outorga (SCHRITZMEYER, 2012, p. 179).

Ao reconhecer a existência da estrutura cênica; forjado, mimeticamente, o enredo querelante, cumpre perscrutar, sucintamente, o papel etiológico desempenhado pelas suas personagens principais diante de um pensamento criminológico crítico.

\section{Distasia Entre Jurados e Réu}

Ao Tribunal do Júri, pedra angular do Estado Democrático de Direito, por ora, reservou-se a apreciação dos crimes dolosos contra a vida: homicídio, infanticídio, participação em suicídio, feminicídio, aborto - tentados ou consumados - e delitos conexos. Em seu âmbito de jurisdição especial, destacam-se duas fases: judicium accusationis e judicium causae. A primeira, anterior, trata da admissibilidade da acusação perante o Tribunal competente. Principia com a oferta da denúncia e finda com a sentença de pronúncia, impronúncia, desclassificação ou absolvição sumária. A segunda etapa, por seu turno, refere-se ao juízo da causa. Inicia-se 
Humanos

Democracia

a partir da sentença de pronúncia com viés in dubio pro societate, ou seja, a admissão da imputação feita ao acusado por reconhecer indícios de materialidade e autoria ou participação. Ultima-se, entretanto, com a prolação da decisão final do juiz presidente do Tribunal Popular.

Imperioso reiterar, ademais, tratar-se este artigo dos aspectos centrais observados no transcurso de várias sessões no Sinédrio Popular. Neste diapasão, cuidou-se de empreender generalizações cognitivas com o fito único de facilitar a articulação didático-descritiva do tema em comento, a partir da observação do império de uma classe de clientela habitual.

Enunciada esta assertiva hermenêutica, considera-se que, para além de servir como instrumento medidor do grau de reprovabilidade social da conduta sub judice, no Tribunal do Júri, remanesce um abstruso sentimento de vindita social, teoricamente desatrelado de tecnicismo, alheio à normatização positivada e insciente da doutrina codificada, mas que age ao talante de sua consciência momentânea influenciável, do interesse punitivo particular e do edifício moral a que se filia, mesmo porque, "numa ordem jurídica democrática, o processo penal tem o desiderato de servir como instrumento de contenção do poder estatal e de maximização da eficácia dos direitos e garantias fundamentais, em detrimento de movimentos de lei e ordem" (LOPES JÚNIOR, 2005, p. 1).

Na plenária, ante a perplexidade em que se vê envolto o jurado pela complexidade das questões, os argumentos valem menos pela sua solidez e conclusividade do que pela forma teatral com que são expostos. As partes utilizam-se do rebusco de linguagem visando induzir o jurado a inferir disso o saber e conseqüentemente a credibilidade. Prima a teatralização dos gestos, o apelo à emoção, o jogo de provocações, ironias, chicanas, estratagemas. Reina a falácia. Prevalece a experiência (MEZZOMO, 2003).

Assim sendo, o Conselho de Sentença, vox populi, soberano em seu julgamento e leigo, deve atuar com equilíbrio, fruto da solidão da consciência; bom senso, produto da razão e livre de qualquer fundamentação jurídica, sem, no entanto, descurar da razoabilidade e ética processuais, tampouco adquirir um caráter de onipotência ou arbitrariedade, mas balizado por princípios e garantias assecuratórias de estrita submissão à Carta Magna, com vistas a consubstanciar o devido processo legal e a plenitude de defesa.

A este grupo de leigos, teoricamente alijado de tecnicismos jurídicos, cabe analisar os fatos e, então, construir uma verdade responsiva a partir de um caleidoscópio de versões e relatos tendenciosos das partes. Não há que se falar sequer em buscar a verdade absoluta, nem esgrimi-la contra a dicotômica alegada verdade real. No Tribunal do Júri busca-se apenas uma concatenação lógica de descrições narrativas eivadas de interesses mercê, principalmente, do aprofundamento processual e performance, de certa forma condizente com a verdade formal buscada pelo próprio Processo Penal em sentido amplo. Aos jurados, agir secundum constientia é corolário prévio à consecução dos ditames legais.

Uma das críticas mais contundentes que se pode fazer ao Tribunal do Júri é que neste os seus julgadores decidem imbuídos basicamente da emoção, com seu instinto, ignorando em grande escala a racionalidade e a técnica jurídica (porque estes não têm formação jurídica). E suas decisões estão protegidas pela soberania dos veredictos e pelo juízo de íntima conviç̧ão (STRECK, 2001, p. 92). 
Nisto reside a diferença entre garantir-se, efetivamente, ao réu a plenitude da defesa ou assegurar-Ihe a conformação de um teatro dramático-épico acusatorial cujo objetivo é, unicamente, promover a vindita social como propaganda da elucubração do poder Judiciário. Sob este viés, cumpre salientar que o direito penal do autor "ao menos em sua manifestação extrema, é uma corrupção do direito penal, em que não se proíbe o ato em si, mas o ato como manifestação de uma forma de ser do autor, esta sim considerada verdadeiramente delitiva" (ZAFFARONI, 2004, p. 107).

Conforme leciona Nucci (1999, p. 183), “a missão de julgar requer profissionais e preparo, não podendo ser feita por amadores. É impossível [neste atual sistema processual] constituir um grupo de jurados preparados a entender as questões complexas que, muitas vezes, são apresentadas para a decisão no Tribunal do Júri" e que reclamam a compreensão de pressupostos principiológicos e de expressões típicas do jargão do Direito.

Para contrabalançar a carência de preparo técnico, involuntariamente ou por artifícios oratórios performáticos (factum externum), o julgador leigo, prenhe de amarras e conjecturas pessoais (factum internum), tende a tributar a filigranas do acervo probatório uma maior valia, emprestando-lhe mestria sobejamente falsa, levando-o, por fim, a um equívoco conclusivo pela inversão parcial da valoração lógica (BONFIM, 2012).

Isso inviabiliza a construção de um ideal acerca da existência de um jurado imparcial o que, inclusive, é ratificado por Mezzomo (2003):

Não há juiz totalmente imparcial. Sempre, em qualquer apreciação, aliás em qualquer ato, está presente uma carga ideológica e cultural, que interfere na visão que temos do mundo e dos fatos, mormente em se tratando de julgar. Mas todas as ciências chegam invariavelmente a um ponto em que a realidade há de ceder ao dogma, pois é imprescindível uma base sólida e intangível a questionamentos.

[...] Pois bem, se por um lado podemos afirmar que não há juiz verdadeiramente imparcial, por outro podemos afirmar que o conjunto de garantias processuais, e sobretudo o julgamento pelo togado, mantém a imparcialidade sob controle. No que diz respeito a jurado leigo, esta garantia se torna mais tênue.

[...] O leigo, ao contrário, repentinamente se vê lançado em uma função nova e desconhecida, em um universo estranho cuja linguagem desconhece, o que o leva a julgar pelo que já conhecia "extra-oficialmente" do caso, ou baseado em provas sobre as quais lança um juízo apressado e por vezes desatento, tolhido que está pelo cansaço de horas a fio. Isto quando não julga impulsionado por interesses próprios.

Hoje, a situação se agrava ainda mais pela expansão dos meios de comunicação. [...] Por fim, o alarmismo e o sensacionalismo de certos segmentos da imprensa, ávidos de lucros, ao realçar ondas de violências, fictícias ou verdadeiras, não importa, acaba gerando no jurado a expectativa de livrar-se do sentimento de impotência perante este quadro, e ele condena descarregando no réu todo esse sentimento, ou o absolve, com medo de tornar-se mais uma vítima.

Como visto, o despreparo técnico e o desconhecimento pretérito do processo são substituídos, em muito, pela saturação sociológica com a violência no quartel hodierno. Sobretudo "quando acalentado por influxos heterodoxos que partem de diversos subsistemas sociais como a opinião pública sublevada em seus próprios medos e preconceitos e uma imprensa vocacionada a produzir resultados nem sempre edificantes" (NOGUEIRA, 2008). Há um processo 
de celebrização da violência urbana, alçada a tema central de jornais televisivos e impressos, não como rechaço social ou apelo pela pacificação gregária, mas como instrumento venal de entronização da patologia comunitária e mercantilização da tragédia humana. A mídia, em quaisquer de suas formas, atulha o homem comum com desgraças e miséria, consolidando no inconsciente coletivo uma repulsa ao status de sujeito criminoso, independentemente da forma ou circunstância em que se corporificou o fato, insubordinando-se a qualquer positivismo jurídico. Ratifica, então, aquilo que Foote Whyte (2005) chamou, etnograficamente, de "sociedade de esquina", ou seja, um conflito inevitável entre o comportamento exigido por aquela posição [do agente criminoso] e o comportamento imposto por sua condição de miséria", "pela maneira como as pessoas representam simbolicamente seu mundo para si mesmas" (p. 272-273) e como as outras as percebem.

Neste diapasão, vale o adágio popular: crime é crime e bandido bom é bandido preso ou morto.

Nos julgamentos pelo Júri, há uma reconstrução do tempo vivido pelos réus. Suas vidas são reelaboradas a partir da constatação da repetição ou não de comportamentos social e legalmente recrimináveis. Se, com o passar dos anos, os réus repetiram atitudes consideradas socialmente "positivas" (trabalharam honestamente, criaram seus filhos e ajudaram sua família, dando-lhes alimento, estudo, saúde, moradia, etc.), a ocorrência criminal de que são acusados pode ser percebida como uma exceção, da qual se pode desconfiar. Do contrário, se suas vidas revelam um acúmulo de "más condutas sociais", a acusação criminal em julgamento se torna quase uma decorrência esperada (SCHRITZMEYER, 2012, p. 157).

Aqui não se cuida de vitimização dos estamentos sociais inferiores, senão de constatação estatística, sem qualquer influência ou respaldo dogmático de cunho antropológico ou sociológico. De acordo com os dados livres do Infopen, sistema integrado de informações penitenciárias do Ministério da Justiça, " $56 \%$ da população prisional é composta por jovens" e, em relação à raça, cor ou etnia, " $67 \%$ da população carcerária é negra". No que diz respeito ao grau de escolaridade, "a média nacional de pessoas que não frequentaram o Ensino Fundamental ou o têm incompleto é de 50\%". Destaca-se, ademais, que apenas $8 \%$ da população prisional completou o Ensino Médio e, como dito,

a grande maioria dos acusados provém das classes menos favorecidas, em contraponto com seus julgadores (provenientes majoritariamente da classe média). E não raras vezes os réus têm antecedentes criminais e estes são usados amplamente como arma da acusação para obter uma condenação e em grande parte isto se torna possível em razão de que o convencimento dos jurados não precisa ser motivado (KIRCHER, 2008).

Neste cenário, "o fracasso de sua própria organização social em se interconectar com a estrutura da sociedade a sua volta" (WHYTE, 2005, p. 276) faz do réu, se preso, fardado como culpado, oriundo de um sistema carcerário, reconhecidamente falido, chegar à sessão acusatorial, perceptivelmente, culpado. Se não formal, decerto proverbialmente. A vestimenta padronizada, a condição de resignação própria do indivíduo achacado e a aura de empodera-

INFOPEN. 2014. Disponível em: <http://portal.mj.gov.br/data/Pages/MJD574E9CEITEMID598A21D892E444B5943A0AEE5DB94226PTBRIE>.htm. 
mento quase divinal daqueles que o cercam logram inferiorizar ainda mais a condição inumana do acusado: a violência e a impotência perante tal fato lhe aviltam a cidadania (VELOSO, 2010). É, ali, naquele palco, em que o Têmis mais claramente empunha sua espada, que o Estado, a contrario sensu, conforma o réu em reles dejeto social.

Nesta senda, contra o que Baratta $(2002$, p. 86) chamou de commitment to deviance, torna-se impossível compreender a criminalidade, sob o viés do Tribunal do Júri,

se não se estuda a ação do sistema penal, que a define e reage contra ela, começando pelas normas abstratas até a ação das instâncias oficiais (polícia, juízes, instituições penitenciárias que as aplicam), e que, por isso, o status social do delinqüente pressupõe, necessariamente, o efeito da atividade das instâncias oficiais de controle social da delinqüência, enquanto não adquire esse status aquele que, apesar de ter realizado o mesmo comportamento punível, não é alcançado, todavia, pela ação daquelas instâncias (BARATTA, 2002, p. 86)

As indumentárias do réu, negativamente distintivas, em contraste com as vestes talares utilizadas pelos demais participantes do procedimento, a apresentação solene do apenado, em marcha subserviente, simbolizando a sua exposição como culpado e, até mesmo, a oportunização da confissão, precedida de alertas acerca das benesses de seu oferecimento, reforçam um apelo que rememora o caráter expiatório do processo medieval (FOUCAULT, 2008).

Completa-se, então, a cenografia perfeita e etiquetam, socialmente, o indivíduo, pois as classes detentoras do poder político/econômico conformam o núcleo intangível da dominação social, cuja hierarquia, no sistema penal, serve para criar uma população criminosa por excelência (LOPES, 2002, p. 72), influenciando a percepção externa, uma vez que as técnicas de estigmatização do comportamento do indivíduo "se identificam, em primeiro lugar, com os processos de definição do senso comum, [...], antes mesmo que as instâncias oficiais intervenham, ou também de modo inteiramente independente de sua intervenção" (BARATTA, 2002, p. 94). Tal sistemática se reproduz no Conselho de Sentença.

Aliado à estatística condição de pobreza imanente que se lhe abraça desde a liberdade vetusta, sua postura no Tribunal do Júri é, naturalmente, subserviente, vituperiosa. Assume, por acessão natural, a pecha de bandido, pesa-Ihe a impressão exterior da culpa e da marginalização.

Neste viés, a roupa é, indubitavelmente, insígnia de culpabilidade e constrangimento, pois "é certo que se o acusado for a julgamento popular com o "macacão" do presídio, causará influência indevida no ânimo dos senhores jurados, que tenderão a condená-lo, bem como a presumir culpa e risco à sociedade" (COSTA JÚNIOR, 2015). Por esta razão, mister atentar e fazer cumprir as resoluções da Organização das Nações Unidas 663 C (XXIV), de 31 de julho de 1957, e 2076 (LXII), de 13 de maio de 1977, que estabeleceram regras mínimas para o tratamento dos reclusos, mormente quando assentaram que, "em circunstâncias excepcionais, sempre que um recluso obtenha licença para sair do estabelecimento, deve ser autorizado a vestir as suas próprias roupas ou roupas que não chamem a atenção". Tal regramento converge para o respeito a um padrão mínimo de dignidade humana e que, no âmbito do Tribunal do Júri, reveste-se de um princípio fundamental de maior relevo: a presunção de inocência. 


\section{Humanos e}

Democracia

Outrossim, há seletividade no exercício de poder do sistema penal, escolhendo alguns indivíduos - geralmente cidadãos marginalizados dos setores mais frágeis da sociedade - para servir de exemplo em espetáculos de exposição midiática, representando não só uma exposição do acusado como um elemento vil, cuja extirpação do convívio social é necessária, como aquilo que representa o mal no imaginário popular (ZAFFARONI, 1999, p. 15).

Este sinal infamante contraria pressupostos basilares do Sistema Penal,

apresentado como igualitário, atingindo igualmente as pessoas em função de suas condutas [...] É também apresentado como justo, na medida em que buscaria prevenir o delito, restringindo sua intervenção aos limites da necessidade [...] quando de fato seu desempenho é repressivo, seja pela frustração de suas linhas preventivas, seja pela incapacidade de regular a intensidade das respostas penais, legais ou ilegais. Por fim, [...] se apresenta comprometido com a proteção da dignidade humana [...] quando, na verdade, é estigmatizante, promovendo uma degradação na figura social de sua clientela. [...]" (BATISTA, 2007, p. 25-26).

Ainda que, teoricamente, viceje o direito penal do fato, no Tribunal do Júri, formado por juízes leigos que decidem de forma imotivada, tem-se por temerária a presença de um símbolo de culpa tão vívido e gravoso. Noutra ótica, consubstancia uma forma degradante de tratamento, posto que induz, subliminarmente, uma pré-condenação, afetando, de alguma forma, a sensação de justiça e a imparcialidade imperativas naquele ambiente.

Sob este mesmo pálio, Nucci (1999, p. 150) defende que

as partes, antes da instalação da sessão, deveriam ter a oportunidade de fazer algumas perguntas aos jurados presentes e ainda não sorteados, buscando extrair seus preconceitos e modos particulares de pensar e agir, a fim de que, a título de exemplo, um comerciante que já foi assaltado várias vezes não tome parte no Conselho de Sentença para julgar um réu acusado de homicídio seguido de roubo. Ou que uma pessoa, extremamente religiosa, entendendo que somente quem julga é Deus, não seja levada a deliberar acerca de um perigoso marginal.

A isso, em que pese a exigida e comprovada capacitação dos julgadores togados e do corpo de serventuários da Justiça, soma-se o despreparo técnico, o desinteresse e má vontade daqueles intimados, à revelia, a tomarem assento no Conselho de Sentença. Revestidos da função pública, representando o Estado gregário, ignoram, por vezes, a relevância da toga que, temporariamente, oprime-lhe os ombros, desenobrecendo a pulcritude do ofício.

[...] São pessoas despreparadas para julgar, pois desconhecem os conhecimentos específicos necessários da área jurídica. E não podemos nos escorar sob o manto da representação democrática e do exercício pleno da cidadania, isto porque a cidadania e a democracia são muito mais que isso, elas representam acima de tudo um julgamento justo e imparcial.

[...] Não se pode ficar à "mercê" apenas do bom senso e da sensibilidade dos jurados para que se tenha justiça (KIRCHER, 2008).

Consectariamente, "o furor despertado pelos meios de comunicação quando do exercício da atividade informativa pode subverter o rito pelo qual deve seguir o processo e até mesmo comprometer a imparcialidade do julgador, influenciando o veredicto a ser prolatado ao final do julgamento" (CÂMARA, 2011). Com isso, olvida-se que a sociedade é multifacetada 
e poliforme e que criminosos são, similarmente, detentores de direitos e prerrogativas legais, tal como inclusão e respeito à dignidade. Todavia, com o ânimo de resguardar uma sociedade já trôpega, aplacar o sentimento comunitário de vitimização social e distinguir polos opostos na existência coletiva, furtam-Ihes a validade moral e a visibilidade humana (VELOSO, 2010).

Dessarte, para além de viciar o julgamento, há o risco da condenação por antecipação, da construção prévia da decisão, independentemente da concreção dos fatos apresentados, da objetividade das perícias, dos argumentos conjecturados e até da própria verdade. $\mathrm{O}$ Tribunal do Júri passa a ser uma etapa formal despicienda, pois já há juízo expiatório constituído. Com a neurose do imediatismo e da espetacularização do crime, forjam-se maniqueísticos bandidos e heróis midiáticos, constroem-se pelourinhos digitais, tolhe-se a defesa do acusado e expurga-se o in dubio pro reo.

A ingerência espetacularizada dos meios de comunicação nos acontecimentos afetos ao sistema de justiça criminal arreda o Direito Penal de seus alicerces teóricos intrínsecos (tais quais o princípio da intervenção mínima e o princípio da fragmentariedade, entre outros), conferindo ao mesmo uma conotação meramente simbólica.

[...] O direito penal simbólico, pois, lança seus tentáculos sobre a política criminal, dando azo ao recrudescimento de penas e criminalização de condutas. Tal panorama é engranzado a partir de casos-símbolos que inflamam o movimento de lei e ordem, ocasionando um distanciamento do Direito Penal com o caráter fragmentário que deveria regê-lo (CÂMARA, 2011).

Notadamente, estabelece-se sobre os atores do julgamento pelo júri um espectro de desconhecimento e dissociação de valores que, não raramente, culmina em prejuízos para o réu.

\section{Fragilidade Substancial das Decisões}

Este artigo, entretanto, sem descurar da importância, eximir-se-á de perquirir a magnitude constitucional dos direitos de primeira geração e da liberdade de imprensa ou o sucedâneo direito à informação, tampouco aprofundar-se-á o rito penal. Atacar-se-á, como projetado até o presente, o funcionamento do Tribunal do Júri sob o panorama dos direitos humanos do réu.

Na esteira do ora em comento, mister ponderar, outrossim, que

[...] no Tribunal Popular, vige o princípio da decisão por íntima conviç̧ão (imotivada), ou seja, as decisões proferidas ali não se sujeitam à fundamentação, os jurados não precisam dizer as razões pelas quais decidiram de tal maneira (não são obrigados a decidir conforme as provas).

[...] Na decisão do Júri, tem-se uma legitimidade para que a sua decisão seja desprovida de qualquer motivação, não havendo qualquer recurso para sanar tal absurdo (KIRCHER, 2008).

O preceito disposto no artigo 93, IX, da Constituição Federal (BRASIL, 2015) determina a fundamentação transparente das decisões dos órgãos do poder Judiciário, sob pena de nulidade. Contra a decisão motivada do magistrado, o códex processual prevê recurso. No Siné- 
Humanos

Democracia

drio Popular, por seu turno, a decisão do Conselho de Sentença é soberana. Conquanto seja uma conquista constitucional histórica, é, concomitantemente, um nítido apelo à qualificação do órgão julgador colegiado.

A fundamentação é o substrato jurídico para corporificar a matéria recursal e, com isso, assegurar o decantado princípio do duplo grau de jurisdição. Neste contexto, atesta-se a relevância

da indispensabilidade da motivação, hoje por preceito constitucional, inclusive nos casos em que o juiz pode decidir discricionariamente. Há uma falsa ideia de que o ato discricionário não precisa ser fundamentado. Gostaria de repelir, energicamente, essa concepção. Diria que, quando o ato é discricionário, é mais necessário ainda que seja motivado, pois, do contrário, converter-se-ia em simples manifestação de arbítrio: sic volo, sic iubeo (expressão em latim, que significa: estou decidindo assim porque quero), o que não se coaduna com os princípios do nosso ordenamento. Desse modo, sobretudo quando a lei concede ao juiz a possibilidade de optar por uma dentre várias soluções, aquela que the parecer mais conveniente, o juiz deverá fundamentar sua escolha (MOREIRA, 1999).

A motivação da decisão é, portanto, figura basilar à compreensão do processo lógico de construção da sentença e pilar para a consolidação dos direitos e garantias fundamentais.

Começa por recordar que o direito a um processo equitativo exige, em regra, que as decisões sejam motivadas, o que se compreende facilmente: o interessado deve ser persuadido de que se fez justiça e que os meios articulados foram examinados pelo juiz; e a enumeração dos pontos de facto e de direito sobre os quais se funda a decisão deve permitir-lhe avaliar as probabilidades de sucesso dos recursos.

A motivação é, por conseguinte, um elemento de transparência da justiça, inerente a qualquer acto jurisdicional.

[...] A motivação é considerada como uma garantia fundamental do "direito do acusado a um processo justo", [...] considerada como um elemento essencial para que a motivação constitua um remédio contra o arbítrio, ou, dito de outro modo, para sujeitar a decisão a um maior controlo da parte da colectividade (ROCHA, 1998).

Ex positis, é razoável aceitar que simplórios monossílabos "sim" e "não", em um país sob a égide constitucional de um Estado Democrático de Direito, tenham o condão de transformar a vida de um indivíduo?

A ausência de técnica científica é, por obviedade, um fator complicador para alcançar-se a fundamentação aqui defendida. $O$ arbítrio da unilateralidade racional, entretanto, fruto das paixões e preconceitos, da emoção inconsciente, da formação cultural e acadêmica e da lida diária, não deve, similarmente, sobrepor-se à dignidade das garantias fundamentais do homem, nem restringir direitos. As medidas fragmentárias de Direito Penal devem continuar sendo a ultima ratio e não instrumento primaz de repressão à irrefreável violência urbana.

Por derradeiro, em robusta digressão final generalizante sobre a sujeição do réu às idiossincrasias do Tribunal do Júri, é imperioso salientar, ainda que en passant, o desgaste compleicional das instituições, sobejamente o Ministério Público e a Defensoria Pública. Ambos viram, desde 1988, o recrudescimento das funções e importância, sem a necessária contrapartida estrutural, material, logística e financeira. Especificamente no que respeita às Defensorias Públicas, "a autonomia funcional e financeira de tal instituição apresenta-se 
comprometida, pois, na grande maioria das vezes, existe uma subordinação a outros órgãos que compõem o Estado, criando a dependência que interfere na atuação de cunho político-administrativo" (CARNELUTTI, 2009). É mais uma vergastada na já débil estrutura de defesa do réu. Conquanto o tema seja de magna saliência social e cuja delicadeza intrincada mereça um estudo analítico apartado, foge ao escopo deste, sendo despiciendo, por ora, aprofundá-lo.

\section{Considerações Finais}

O Tribunal do Júri é a intromissão socioestatal na porção hodierna que mais aflige a humanidade: a violência. É o exercício teatral e direto do poder do povo, sem representação transversa, sem admoestação, promovido pelo Estado para consolidação da democracia. 0 Tribunal Popular, no entanto, tal como se afigura, não é em si mesmo um instrumento de garantia de direitos fundamentais ou de igualação dos indivíduos, tampouco um processo democrático, senão, como máximo, um processo legal e simbólico previsto na democracia.

Destarte, inobstante haver guardado um exame geralista do tema, versou-se, majoritária e deliberadamente, acerca da compleição semiculta do Conselho de Sentença e as questões extrínsecas e intrínsecas que o substanciam.

Sob este lume, a imotivação da decisão, outorgada a este egrégio fórum de administração da Justiça, transcende um preceito geral do método jurisdicional, funcionando, na prática, como a extrapolação alargada da arbitrariedade, com a chancela jurídico-estatal da vindita coletiva e da seletividade social. Imparcialidade, racionalidade, análise ponderada dos fatos e consciência livre são questiúnculas vencidas que apenas teoricamente lavram-se nas atas, prevalecendo a encenação da forma e a consolidação de uma casta de párias etiquetadas.

Com a paz social ameaçada diuturnamente, sob o foco, microscopicamente, amplificado pela mídia sensacionalista, o réu, marginal preconcebido, inserto na generalidade das estatísticas penitenciárias, perece ante o desejo de repressão criminal por que clama a sociedade. Neste caso, a verdade é apenas elemento catártico de um jogo cênico próprio do Tribunal Popular, uma tese parida no seio da verborragia jurídica, mas verba volant, scripta manent. $\mathrm{E}$ a definitividade da decisão? Como borrar, se houver, o erro canhestro do Estado?

Tal questionamento remete a outra indagação, levantada por Ávila (2005): “As vantagens causadas pela promoção do fim são proporcionais às desvantagens causadas pela adoção do meio? A valia da promoção do fim corresponde à desvalia da restrição causada?"

De outra parte, no ofício institucional de zelar pela sociedade, o Ministério Público assume, por vezes, a função de artífice e substituto da insatisfação social, valendo-se de causas, midiaticamente, rumorosas para imprimir o efeito pedagógico do jus puniendi. Ademais, numa perspectiva generalista, no ímpeto de acusar e convencer para bem representar o clamor coletivo, tergiversa-se, vilipendiando a imprescindível lealdade processual. Por isso, é temerário imiscuir-se na grita social, alijando-se da técnica, para dar respostas desejáveis. Pela mesma razão, é infirme ter-se como soberano um julgamento perpetrado por leigos e prescindido de razão explícita, pois se finda por conservar e reproduzir relações sociais desiguais. 
A isto, cumpre anhadir a ingerência irrefreada dos meios de comunicação sobre a Justiça Criminal. A sanha punitiva criminal não pode resvalar pelo vezo de castigar, a priori, para fazer justiça na sequência: este é o corolário dos direitos humanos e apanágio-mor de um Estado Democrático de Direito, cuja dignidade humana, due process of law e segurança jurídica são, necessariamente, panteões.

É apodítico que o Tribunal do Júri, como cláusula pétrea e garantia fundamental, seja couraça à prepotência e ao arbítrio estatais, mas não se converta em antiveneno à punição justa, por isso impende repensá-lo não como instituto, mas como forma. Não se lhe pode converter em berço de injustiças pelo tíbio motivo de ser histórico, tradicional ou popular.

Inelutavelmente, uma alternativa viável, igualmente ortodoxa e vigente no Brasil, seria o escabinado, no qual juízes togados e leigos incumbem-se tanto de decidir por eventual condenação ou absolvição, quanto por quantificar a pena.

Composto por juízes leigos e togados, o modelo de Tribunal dos Escabinos é a sistemática adotada pela Justiça Militar pátria. Destarte, não haveria ineditismo, mas uma solução processual estratégica para afastar a ignorância do veredicto, reduzir o peso da teatralidade cênica e retórica, incluir a técnica jurídica, empalidecer o nome, a posição social e a condição de vida do réu na capa dos autos processuais, salvaguardando a instituição constitucional do Tribunal do Júri.

Mister mudar o sistema, evoluir ou patere quam ipse fecisti legem.

\section{Referências}

ARISTÓTELES. Poética. Tradução Antônio Carvalho. São Paulo: Difusão Européia do Livro, 1959.

ÁVILA, Humberto. Teoria dos princípios: da definição à aplicação dos princípios jurídicos. 4. ed. São Paulo: MaIheiros, 2005.

BARATTA, Alessandro. Criminologia crítica e crítica do direito penal: introdução à Sociologia do Direito Penal. 3. ed. Trad. Juarez Cirino dos Santos. Rio de Janeiro: Ed. Revan; Instituto Carioca de Criminologia, 2002.

BATISTA, Nilo. Introdução crítica ao direito penal brasileiro. 11. ed. Rio de Janeiro: Revan, 2007.

BONFIM, Edilson Mougenot. Júri: do inquérito ao plenário. 4. ed. São Paulo: Saraiva, 2012.

BRASIL. Código de Processo Penal e Constituição Federal. 55. ed. São Paulo: Saraiva, 2015.

BRECHT, Bertolt. Teatro dialético. Rio de Janeiro: Civilização Brasileira, 1967.

CÂMARA, Juliana de Azevedo Santa Rosa. Sistema penal e mídia: breves linhas sobre uma relação conflituosa. In: Evocati Revista, n. 70, out. 2011. Disponível em: <http://www.evocati.com.br/evocati/interna.wsp?tmp_page=interna\&tmp_codigo=497\&tmp_secao=16\&tmp_topico=direitopenal\&wi.redirect=4EBUDAFDL6IKM1AOMJJN>. Acesso em: 18 jun. 2016.

CARNELUTTI, Francesco. As misérias do processo penal. 2. ed. São Paulo: Saraiva, 2009.

COSTA JÚNIOR, Osny Brito da. Roupas de carceragem no júri e a dignidade da pessoa humana. 2015. Disponível em: <http://aurineybrito.jusbrasil.com.br/artigos/160205971/roupas-de-carceragem-no-juri-e-a-dignidade-da-pessoa-humana>. Acesso em: 18 jun. 2016.

D'URSO. Luiz Flávio Borges. O réu tem o direito de mentir? In: Âmbito Jurídico, Rio Grande, VI, n. 14, ago. 2003. Disponível em: <http://www.ambito-juridico.com.br/site/index.php?n_link=revista_artigos_leitura\&artigo_ id=3958>. Acesso em: 22 jun. 2016.

FERREIRA, Marco Aurélio Gonçalves. A ausência do crime de perjúrio no sistema jurídico brasileiro. Rev. SJRJ, Rio de Janeiro, v. 17, n. 29, p. 143-150, dez. 2010. Disponível em: <http://www4.jfrj.jus.br/seer/index.php/revista_sjrj/article/viewFile/193/203>. Acesso em: 25 jun. 2016.

FOUCAULT, Michel. Vigiar e punir: história da violência nas prisões. 35. ed. Petrópolis: Vozes, 2008.

GOMES, Luiz Flávio. Princípio da não autoincriminação: significado, conteúdo, base jurídica e âmbito de incidência. Disponível em: <http://ww3.lfg.com.br/public_html/article.php?story=20100126104817603>. Acesso em: 25 jun. 2016. 
KHADER, Eliana. História do Tribunal do Júri: a origem e a evolução no sistema penal brasileiro. Disponível em: <http://www.tjrj.jus.br/c/document_library/get_file?uuid=4e0d5d15-dcef-412a-b09f-2da986081186\&groupld=10136>. Acesso em: 25 jun. 2016.

KIRCHER, Luís Felipe Schneider. Visão crítica (garantista) acerca do tribunal do júri. In: Âmbito Jurídico, Rio Grande, XI, n. 55, jul. 2008. Disponível em: <http://www.ambito-juridico.com.br/site/index.php?n_link=revista_artigos_leitura\&artigo_id=3036\#_edn6>. Acesso em: 25 jun. 2016.

LIMA, Roberto Kant de. Cultura jurídica e práticas policiais - a tradição inquisitorial. 1982. Disponível em: <http:// www.anpocs.org.br/portal/publicacoes/rbcs_00_10/rbcs10_04.htm>. Acesso em: 25 jun. 2016.

LOPES JÚNIOR, Aury. Direito Processual Penal. 12. ed. Saraiva: São Paulo, 2015.

Introdução crítica ao processo penal: fundamentos da instrumentalidade garantista. 2. ed. Rio de Janeiro: Lumen Juris, 2005.

LOPES, Luciano Santos. A contribuição de Alessandro Baratta para a criminologia crítica. De jure: revista jurídica do Ministério Público do Estado de Minas Gerais, n. 11, p. 69-80, jul./dez., 2008.

MEZZOMO, Marcelo Colombelli. Tribunal do Júri. Revista Jus Navigandi, Teresina, ano 8, n. 62, 1 fev. 2003. Disponível em: <http://jus.com.br/artigos/3690>. Acesso em: 25 jun. 2016.

MINISTÉRIO DA JUSTIÇA. Brasil. Levantamento nacional de informações penitenciárias Infopen - junho de 2014. Departamento Penitenciário Nacional. Disponível em: <http://www.justica.gov.br/noticias/mj-divulgara-novo-relatorio-do-infopen-nesta-terca-feira/relatorio-depen-versao-web.pdf>. Acesso em: 17 jul. 2016.

MORAES, Alexandre de. Direitos humanos fundamentais. 3. ed. São Paulo: Atlas, 2000.

MOREIRA, José Carlos Barbosa. O que deve e o que não deve figurar na sentença. Revista da Emerj, v. 2, n. 8, 1999. Disponível em: <http://www.emerj.tjrj.jus.br/revistaemerj_online/edicoes/revista08/Revista08_42.pdf>. Acesso em: 17 jul. 2016.

NOGUEIRA, Roberto Wanderley. Estado não pode impor culpa com base na opinião pública. Consultor Jurídico, São Paulo, 15 maio 2008. Disponível em: <http://www.conjur.com.br/2008-mai-15/estado_nao_impor_culpa_ base_opiniao_publica>. Acesso em: 6 maio 2017.

NUCCl, Guilherme de Souza. Júri: princípios constitucionais. São Paulo: Juarez de Oliveira, 1999.

Tribunal do Júri. 3. ed. São Paulo: Revista dos Tribunais, 2008.

QUEIJO, Maria Elizabeth. $O$ direito de não produzir prova contra si mesmo (o princípio nemo tenetur se detegere e suas decorrências no processo penal). São Paulo: Saraiva, 2003.

REPÚBLICA PORTUGUESA. Tribunal da Relação do Porto. Processo no 0341618. Relator: Conceição Gomes. 2004. Disponível em: <http://www.dgsi.pt/jtrp.nsf/0/f5ee94c73812e71d80256e220036ab54?OpenDocument>. Acesso em: 14 jul. 2016.

ROCHA, Manuel António Lopes. A motivação da sentença. In: Documentação e Direito Comparado, n. 75/76, 1998. Disponível em: <http://www.gddc.pt/actividade-editorial/pdfs-publicacoes/7576-c.pdf>. Acesso em: 17 jul. 2016.

SCHRITZMEYER, Ana Lúcia Pastore. Jogo, ritual e teatro: um estudo antropológico do Tribunal do Júri. São Paulo: Terceiro Nome, 2012.

STRECK, Lenio Luiz. Tribunal do júri: símbolos e rituais. 4. ed. Porto Alegre: Livraria do Advogado, 2001.

TOURINHO FILHO, Fernanda da Costa. Manual de Processo Penal. 9. ed. São Paulo: Saraiva, 2007.

VELOSO, Letícia Helena Medeiros. Vítimas, bandidos ou cidadãos? Interpretando a relação entre jovens, cidadania e violência etnográficos e da escola de Chicago. Confluências - Revista Interdisciplinar de Sociologia e Direito, v. 11, n. 2, p. 69-90, 2010.

ZAFFARONI, Eugenio Raúl. Em busca das penas perdidas: a perda de legitimidade do Sistema Penal. 4. ed. Rio de Janeiro: Revan, 1999.

Manual do Direito penal brasileiro: parte geral. 5. ed. rev. atual. São Paulo: Revista dos Tribunais, 2004.

WHYTE. William Foote. Sociedade da esquina: a estrutura social de uma área urbana. Trad. Maia Lúcia de Oliveira. Rio de Janeiro: Jorge Zahar Ed., 2005. 